its treatment on driving performance. Int Clin Psychopharmacol 1988;3(Suppl 1):59-66.

9 Shakow D. Psychological deficit in schizophrenia. Behav Sci 1963;8:275-305.

10 Savage PPE, Wilkinson V. Reaction time in psychiatric patients: pilot study. $N Z$ Med F 1971;73:285-8.

11 Bech P. Mental illness and simulated driving: Before and during treatment. Pharmacopsychiatry 1975;8:143-50.

12 Shagass C, Roemer RA, Amadeo M. Eye-tracking performance and engagement of attention. Arch Gen Psychiatry 1976;33:121-5.

13 American Psychiatric Association. Diagnostic and Statistical manual of mental disorders, (3rd ed). Washington DC: APA 1980.

14 Overall JE, Gorham DR. The Brief Psychiatric rating scale. Psychol Rep 1962;10:799-812.

15 Simpson GM, Angus JWS. A rating scale for extrapyramidal side effects. Acta Psychiatr Scand 1970;212(Suppl): 11-9.

16 Simpson GM, Lee JH, Zoubok B, Gardos G. A rating scale for tardive dyskinesia. Psychopharmacology 1979; 64:171-9.

17 Hindmarch I. Psychoactive drugs and driving. Psychiatry in Practice 1986;5:6-10.

18 Whiteman PD, Fowle ASE, Hamilton MJ, et al. The pharmacokinetics and pharmacodynamics of procyclidine in man. Beckenham; Wellcome Group Research and Development, 1982

19 Silverstone T. Drugs and driving. Br $\mathcal{f}$ Clin Pharmacol 1974;1:451-4.

20 Consensus Development Panel. Drug concentrations and driving impairment. $\mathcal{F} A M A 1985 ; 254: 2618-21$.

21 Department of Transport and The Central Office of Information. The Highway Code. London: HMSO 1978:14, 72 .

22 Nicholson AN. The significance of impaired performance. Int Clin Psychopharmacol 1988;3(Suppl 1):117-27.

23 Hindmarch I. The psychopharmacological Approach: Effects of psychotropic drugs on car handling. Int Clin Psychopharmacol 1988;3(Suppl 1):73-9.

\section{Sir Charles Bell 1774-1842}

In non-medical circles the best-known Bell is Joseph Bell (1837-1911) who was the source of inspiration and example for Conan Doyle's living legendSherlock Holmes. Bell's palsy is probably better known to doctors, but was not described by Joseph, but by the unrelated Sir Charles Bell, ${ }^{1}$ though Avicenna had much earlier described spastic, atonic and convulsive types of facial palsy. ${ }^{23}$

Born in Edinburgh, Charles Bell lectured in anatomy and surgery. In 1807 he distinguished between the sensory and motor nerves of the brain. In 1812 he was appointed to the Middlesex Hospital and studied gunshot wounds at Haslar Hospital after the battle of Corunna in 1809. After Waterloo he worked in Brussels. Studies of the spinal nerves led to furious arguments with Francois Magendie. Bell's experiments showed that: "stimulation of the anterior portion of the spinal marrow (spinal roots) convulsed animals more certainly than injury to the posterior portions". He recognised "four brains": two anterior (cerebral) and two posterior (cerebellar) ... . with full communications to ensure "their acting with perfect sympathy". $4 \mathrm{He}$ concluded: "the cerebrum and cerebellum were parts distinct in function and that every nerve possessing a double function obtained that by having a double root."

He worked on the brain which united the mind to the body: "Into it all the nerves from the external organs of the senses enter . . . nerves from the surface, nerves of touch, and nerves of peculiar sensibility; . . . and from it all the nerves which are agents of the will pass out" (via the anterior columns of the cord and its roots). "The cerebellum governs the operation of the viscera . . . their nerves go everywhere for the secret operations of the bodily frame ..."
The facial nerve he called "the respiratory nerve of the face". "In all the exhilarating emotions, the eyebrows, eyelids, the nostrils and the angles of the mouth are raised. In the depressing passions it is the reverse." 5

Bell entered another controversy when after experiments on the nerves in the ass, he erred in asserting that the fifth and seventh cranial nerves innervated the muscles of the face. Mayo (1796-1852) had earlier given the correct anatomy, but Bell later corrected his error: "the sensibility of the head and face depend upon the fifth pair of nerves . . the portio dura of the seventh nerve is the principal muscular nerve of the face". 6

Bell was a brilliant and versatile if controversial figure, well versed in comparative morphology, a prolific writer and a gifted water colour painter: the Royal College of Surgeons in Edinburgh contains many of his superb pictures of war injuries and anatomical exposures.

JMS PEARCE

1 Hale-White W. Sir Charles Bell. Great doctors of the nineteenth century. London: Edward Arnold, 1935. $42-62$.

2 Gruner OC. A treatise on the Canon of Medicine of Avicenna incorporating a translation of the first book. London, Luzac, 1930

3 Avicenna (Ibn Sina). Al Qanun fil-Tib. Arabic (Bullaq) ed, vol 2, Book 111. Cairo: Government Press, 1877:103-4. (Translated by Nathan B 1992).

4 Bell C. Idea of a new anatomy of the brain submitted for the observations of his friends. London. Straham and Preston 1811 (private circulation). Facsimile reprinted, Dawsons of Pall Mall, London 1966

5 Bell C. Essays on the anatomy and philosophy of expression, 2nd Essays on the anatomy and phil

6 Bell C. On the nerves of the face, being a second paper on the subject. Phil Trans Royal Soc 1829;119:317. 